\title{
Partner Capabilities and Alliance Time Frame: An Analysis of International Strategic Alliances from the CEE
}

\section{S. Hossein Jalali ${ }^{1}$}

\begin{abstract}
Partner selection is one of the most discussed issues in strategic alliances literature. However, the majority of research has typically focused on generic partner characteristics and presented conceptual models for alliance partner selection, addressing clan image but only limited pieces of the partner selection puzzle. Rooted in the resource-based view, this paper suggests that partner selection is contingent upon the intended time frame of strategic alliances and presents a new and intensive conceptual framework that examines the appropriate partner capability for strategic alliances, in the case of short/medium-term alliances and long-term ones. Based on empirical evidences from 736 alliances in the CEE region, the findings stress the differences between varied partner capabilities in short/medium-term and long-term alliances. Accordingly, the significance of technological capability increases with the number of year's alliances endured. Moreover, the importance of market capability decreases significantly when alliances last for a longer time frame.
\end{abstract}

Keywords: strategic alliance; alliance time frame; partner capabilities; partner selection.

\section{INTRODUCTION}

During the recent decade, the number of international strategic alliances has gradually increased due to the interconnectedness of global market, making them a reliable and popular market entry strategy for being involved in international business. Strategic alliances are well-established collaborative models by which firms gain access to external resources (Hess \& Rothaermel, 2011); rather than either operating on their own or merging their operations (Dussauge, Garrette \& Mitchell, 2000). Indeed, strategic alliances provide firms with opportunities to gain more market power and achieve a faster and more effective entry into the international market (Xia, 2011); and are particularly

1 S. Hossein Jalali, Ph.D. Scholar, Faculty of Management, University of Tehran, Gisha, North Karegar, Tehran, Iran; e-mail: Jalali.sh@ut.ac.ir; e-mail: Jalali.sh@ut.ac.ir. 
effective in helping a firm gain and maintain a superior competitive position in a dynamic, volatile and uncertain international environment.

As firms seek actively to leverage the numerous potential benefits of strategic alliances, they often neglect the potentially detrimental effects of poor alliance partner selection (Shah \& Swaminathan, 2008). Choosing the right partner is a determinant decision in the pre-agreement phase. Many scholars underscored the importance of appropriate partner selection as a critical parameter in alliance success, since superior value creation depends on whether partners represent synergies in the relevant characteristics (Shah \& Swaminathan, 2008; Mitsuhashi \& Greve, 2009; Ahuja, Polidoro, \& Mitchell, 2009; Mindruta, Moeen \& Agarwal, 2016).

As Gomes, Barnes and Mahmood (2016) stated, the choice \& evaluation of partners appears to play a significant role in contemporary research on strategic alliances, particularly due to the growing importance associated with partner selection in alliance activities. Scholars have produced an impressive body of work from different viewpoints on partner selection (Hitt et al., 2000; Hitt et al., 2004; Chen, Lee \& Wu, 2008; Dong \& Glaister, 2006; Li et al., 2008; Shah \& Swaminathan, 2008; Li \& Ferreira, 2008; Doherty, 2009; Wu, Shih \& Chan, 2009; Al-Laham, Amburgey \& Baden-Fuller, 2010; Solesvik \& Westhead, 2010; Meuleman et al., 2010; Roy, 2012; Ahlstrom et al., 2014; Mindruta, Moeen \& Agarwal, 2016), but yet, there are some important limitations.

First of all, we have access to a rich literature about general partner characteristics, yet frameworks that breakdown different characteristics, and addresses when and why managers choose partners with certain, specific characteristics, are understudied. According to Cummings and Holmberg (2012) the vast majority of the prior alliance partner research has been framed in static analysis terms. Given the complexity of partner selection decisions, a generic model for distinctive partner characteristics may be unsuitable for understanding complex phenomena. Distinguishing between partner characteristics due to their nature (i.e., skills, assets, capabilities etc.) and specifying the circumstances under which alliances are studied, could help to understand how firms select their collaborative partners and under what conditions. Against this backdrop, the current research focused primarily on partner capabilities, not all of the characteristics; and then tries to provide insights about partner capabilities due to the time frame of alliances. In addition, the majority of strategic alliances literature has been based on developed economies and hence, their insights are best fitted with alliances from this context. In the recent decade, the strategic alliance concept is growing in appeal to firms in developing economies and is becoming a preferred choice for firms to gain a competitive advantage 
in international markets. However, the highly complex, volatile and largely unknown business environment of developing economies raises the risk of any business collaboration (Li \& Ferreira, 2008). Regarding this issue, the current work applied the theory to the case of wholly export-oriented alliances from developing economies, and provides empirical evidence that is compatible with the contextual conditions of developing economies. The research question thus follows: Which partner capabilities play an important role in short/medium-term or long-term alliances among developing economies-based firms?

This research makes a number of empirical and practical contributions. The most important is that it adds significant new empirical knowledge to the literature on international strategic alliances in a developing economy context and provides a more complete understanding of partner selection decisions. Second, this study focuses on the time frame of alliances. Previous literature rarely provides insights about specific partner selection criteria in each of the short/medium-term or long-term strategic alliances. From the theoretical perspective, we know that long-term strategic alliances are not the same as short/medium-term ones and each of them has particular attributes. It is believed that short/medium-term alliances give freedom of action to independent behaviors, have limited resources exchange, and are excessively prone to conflict and instability. While resources exchange in long-term alliances happens frequently and normally, the separation phase is not arranged and alliances are terminated due to problems associated with the alliance (Bignoux, 2006). Also, this paper has an important managerial implication. Executives that better understand which partner capabilities are best fitted with their strategic alliances; will make a better decision at the stage of partner seeking and evaluation.

The remainder of this paper is organized as follows: The next section contains a brief literature review about international strategic alliances and decision making over partner selection. Then the research methodology, including data collection and measures presents in the subsequent section. The paper continues with a presentation of empirical findings and sensitivity analysis, along with the discussion of the findings, limitations, and directions for future research.

\section{LITERATURE REVIEW}

In the recent decade, the interconnectedness of global market has raised the importance of the ability to seize opportunities from international markets. The task is a challenge requiring both the recognition of new opportunities, 
and also, an understanding of how to obtain market share abroad (Yu, Gilbert \& Oviatt, 2011). In such a situation, a strategic alliance plays an important role as a collaborative solution for firms to expand their activities into international markets (Nakos, Brouthers \& Dimitratos, 2014).

Strategic alliances are voluntary interfirm cooperative arrangements for value creation through access to reciprocal resources, skills and capabilities (Ahuja, 2000; Zhang, Duysters \& Filippov, 2012), and are aimed at achieving the objectives of the partners (Das \& Teng, 2002). Scholars have defined international strategic alliances as a firm's propensity to engage in strategic alliances with foreign partners (Lee \& Park, 2006). Indeed, in international markets, strategic alliances provide firms with the resources and capabilities needed to overcome the liability of foreignness (Nakos, Brouthers, \& Dimitratos, 2014). Firms seeking alliances recognize opportunities for resource complementarity that are best exploited for rents through collaborative operational models rather than through market means or acquisition (Phene \& Tallman, 2014).

Strategic alliances are a very complex phenomenon. Despite the advantages offered by international strategic alliances however, empirical evidence shows few successful alliances (Bierly \& Gallagher, 2007; Arranz, Arroyabe \& de Arroyabe, 2016), especially from a developing economies context (Li \& Ferreira, 2008). Challenges in governance and internal conflicts always threaten the longevity of alliances; however, it can be inferred from the literature that inappropriate partner selection is antecedent of any forthcoming difficulties such as internal tension (Krishnan, Martin \& Noorderhaven, 2006) and is a key determinant of failure in strategic alliances (Bierly \& Gallagher, 2007). Thus, the benefits of alliances for firms depend on the attributes of the alliance's partners (Bae \& Insead, 2004).

Partner selection consists of choosing to ally with someone among the various available options who has the resources you need and whom you can induce, via your own stock of resources, to collaborate with you. This choice relates to what capabilities are being combined in an alliance (Ahuja, Polidoro \& Mitchell, 2009), and is a key decision alongside decisions about governance, structure, and alliance scope (Meuleman et al., 2010). The importance of partner selection can be discussed from different theoretical contexts. From the resource based-view, partner selection is a critical decision in the preagreement phase of strategic alliances formation, because it influences the mix of resources and capabilities which will be available to the alliance (Dong \& Glaister, 2006); and thus, arises complementarity (Shah \& Swaminathan, 2008; Mindruta, Moeen \& Agarwal, 2016).

The partner selection is not a generic, static decision. According to Shah and Swaminathan (2008), alliance type is a critical consideration in evaluating the importance of specific partner characteristics. There is a need to do studies which examine whether, and how, partner selection criteria might vary with 
different types of strategic alliances (Hitt et al., 2000). In theory, mutual gain can be achieved by partners in any type of alliances, however the reality is different. Comparing short/medium-term alliances with long-term alliances revealed the inherent differences between alliances due to their time frame. Firms involved in short/medium-term alliances exchange resources for a prearranged time period in order to achieve a specific objective and separate at the end of that time period. While, in long-term alliances there is no clear time horizon and the alliance is dependent on relational parameters such as trust and reputation of the partners (Bignoux, 2006). Notwithstanding these fundamental differences, there is barely any empirical evidence which provides a classification about the appropriate partner characteristics for short/medium-term and long-term alliances.

Also, the variety of partner characteristics makes it difficult to decide about partner selection and do a comprehensive review on partner characteristics, so it is necessary to limit the theoretical and contextual backgrounds (Hitt et al., 2000); and focus only on some limited dimensions of characteristics. Also, in accordance with Cummings and Holmberg (2012), the criteria for choosing someone to ally will change over time, and so it is important to consider time-based limitation in the alliance partner selection. Thus, the framework of current study is focused narrowly, but deeply, on partner capability among various partner characteristics and provides insights around three fully distinctive and independent capabilities, including market capability, managerial capability and technological capability.

Market capability. Market capability is the first and most explored partner capability in previous studies. As Lu and Beamish (2006) explored, market knowledge is associated with the profitability of collaborative relationships. Parameters such as international market knowledge, local market knowledge, distribution channels, links with major buyers and suppliers, and market relative power are all cited numerously in literature (Dong \& Glaister, 2006). Also, Hitt et al. (2000; 2004) and, Wu, Shih and Chan (2009) directly emphasized on market capability as a determinant characteristic for partner selection.

Managerial capability. As Hitt et al. (2004) indicated, managerial capabilities are not well developed in the firms from a developing economies context. In addition, successful managerial capabilities in developed economies are not compatible with necessitates of developing economies. High levels of volatility, irregularity, and uncertainty of the business environment in developing economies and a lack of managerial capabilities has posed critical competitive problems for firms from developing economies. The managerial capability has conceptualized in a relatively similar way. Hitt et al 
(2000; 2004) and Ahlstrom et al. (2014) referred to managerial capability as a decision-making style and a bundle of knowledge, experiences and skills. However, Bakker (2016) used the diversity along skill and competence-based dimensions among the board of directors in his research. The competence breadth would help scholars to have a more qualified predictor of managerial capability in strategic alliances.

Technological capability. The technological capability is the third distinctive partner capability in the alliance literature. Most authors defined technological capability as; the ability to develop new process or product technologies such as significant R\&D operations; develop and commercialize new products; know-how and so on (Ahlstorm et al., 2014). The main advantage of technological capability is accessibility to non-overlapping technological resources and know-how, which allow firms to more easily respond to the challenges of a discontinuous and turbulent technological breakthrough (Vasudeva, Spencer \& Teegen, 2013). Firms in developing economies often lack the knowledge and capabilities for sophisticated manufacturing and need modern, updated technology to produce qualified products and services to compete in global markets (Hitt et al., 2004). Hence, seeking technological capability gains more importance for the firms from developing economies.

Table 1 presents a list of three distinctive partner capabilities for international strategic alliances, and also recent contributors for each item. This list is not limited to indicate ones, but the theoretical, contextual and time-based concerns would ensure that potentially all important and fully distinctive partner capabilities for international strategic alliances from developing economies, are extracted from the literature.

Table 1. Partner capabilities and recent contributors

\begin{tabular}{|c|c|c|}
\hline Capability & Sub-criteria & Contributors \\
\hline Market Capability & $\begin{array}{l}\text { Increase market share, better } \\
\text { export opportunities, and knowl- } \\
\text { edge of local business practices }\end{array}$ & $\begin{array}{l}\text { Hitt et al. (2000); Mitsuhashi (2002); Hitt } \\
\text { et al. (2004); Chen and Tseng (2005); Wu, } \\
\text { Shih and Chan (2009) }\end{array}$ \\
\hline Managerial Capability & $\begin{array}{l}\text { Managerial experiences, deci- } \\
\text { sion-making processes, and com- } \\
\text { petence breadth }\end{array}$ & $\begin{array}{l}\text { Hitt et al. (2000); Luo (2002); Hitt et al. } \\
\text { (2004); Ahlstrom et al. (2014); Bakker } \\
\text { (2016) }\end{array}$ \\
\hline $\begin{array}{l}\text { Technological Capa- } \\
\text { bility }\end{array}$ & $\begin{array}{l}\text { Technological knowledge, signifi- } \\
\text { cant R\&D expertise, and know- } \\
\text { how }\end{array}$ & $\begin{array}{l}\text { Hitt et al. (2000); Luo (2002); Chen, Lee } \\
\text { and Wu (2008); Gulati, Lavie and Singh } \\
\text { (2009); Chand and Katou (2012); Ahlstrom } \\
\text { et al. (2014); Badir and O'Connor (2015) }\end{array}$ \\
\hline
\end{tabular}

Accordingly, a key question arises as to: Which partner capabilities are best fitted with strategic alliances due to their time frame? Most research 
stated that a strategic alliances' outcome depends on partner characteristics, but limited studies explore the role of specific partner characteristics (Nielsen, 2003; Wyatt, Pathak \& Zibarras, 2010; Arranz, Arroyabe \& de Arroyabe, 2016).

\section{RESEARCH METHODS}

\section{Data collection and sample}

This study focused on partner capabilities and their impact on strategic alliances due to the time frame of alliances. To do this, current research has aimed at three distinctive capabilities including market capability, managerial capability and technological capability and has assessed their impacts on international strategic alliances divided in two groups, short/medium-term alliances versus long-term ones. In order to test the intention of the study, the databases of the Iran Chamber of Commerce, Industries, Mines and Agriculture (ICCIMA) and the Iran Customs Administration (IRICA) were used as an initial sampling frame to find strategic alliances between firms from Central and Eastern European (CEE) countries (Comprising Albania, Bulgaria, Croatia, the Czech Republic, Hungary, Poland, Romania, the Slovak Republic, Slovenia, Estonia, Latvia and Lithuania, according to the OECD) and Iranian firms. So, the initial sample consisted of international strategic alliances between partners from developing economies-based countries.

For sampling, alliances were categorized in two groups, those that have been formed during the last three years (short/medium-term alliances) and those that have endured more than three years (long-term alliances). Then, simple random sampling was used and a sample of 1080 alliances, of which most of them were comprised of two partners, was identified. $59.8 \%$ of the sample is short/medium-term ones and $40.2 \%$ is long-term alliances. All participants received an identical online questionnaire. Prior to the fullscale study, the questionnaire was presented to several experts of different disciplines in strategy and international business to test the difficulties, ambiguities, clarity and validity of measures. Then, a revised version of the questionnaire was used in the full-scale study. Data were collected over a period of five months during 2016. The data collection yielded 736 valid surveys from the managers responsible for developing and managing those alliances (54\% of short/medium-term alliances and $46 \%$ of long-term alliances), making an available return rate of $68.1 \%$. While $13.72 \%$ of the sample comprised of alliances between partners from Iran and three or more CEE countries, the remaining sample including alliances between Iranian firms and partners from Albania (3.67\%), Bulgaria (7.74\%), Croatia (15.35\%), the Czech Republic (9.1\%), Hungary (10.33\%), Poland (13.32\%), Romania (9.78\%), 
the Slovak Republic (5.84\%), Slovenia (5.03\%), Estonia (2.85\%), Latvia (1.36\%) and Lithuania (1.9\%). Nearly half the alliances partners (49.7\%) are large firms with more than 250 employees, while $18.3 \%$ of firms have fewer than 50 employees, and $32 \%$ are firms with employees between 50 and 250 . Overall, the sample represented 8 different manufacturing industries. Petroleum products, mineral products and food manufacturing were represented the most with $39.6 \%, 33.4 \%$ and $22.2 \%$, respectively. These alliances are involved in different markets, but the majority of them (68.2\%) export their products to a target market which is not the origin of any partners, and $20.9 \%$ of them are doing business internationally, without focusing on a specific target market.

\section{Measurements}

The respondents were presented with a questionnaire containing the three partner capabilities, as mentioned in the Table 1. The measurements for each item were derived from the literature and most recent contributors. Respondents were asked to identify their perception of the importance of partner capabilities on each item, which was rated on a five-point scale, ranging from "not at all important" (1) to "very important" (5).

The dependent variable in the current study is the performance of alliances. Due to the scope of this study, the performance of chosen alliances is directly contingent to their performance on international markets. Thus, the scale of Jalali (2012) was used to measure the dependent variable. Although, due to the scope of this study, the performance of short/mediumterm alliances (alliances with less than three years age) and the performance of long-term alliances (alliances endured more than three years) are separated from each other. Also, some variables were used as controls in the analyses because of their potential effect on capabilities. These variables can be categorized in four groups: industry, age, size and experience. Industry type (natural resources and manufacturing) was controlled in the analyses. Each industry type was transformed into a dummy variable; while petroleum products, textile product mills and food manufacturing represented $95.2 \%$ of the sample. Firm age and firm size are other control variables which were calculated as the natural logarithm of the total number of years since the establishment of the firm, and total number of employees. International experiences is the fourth control variable. As firms gain more experiences in international markets, they will better respond to the international markets necessitates. Thus, the international experience of the focal firm, calculated as the total number of years in which the firm had engaged in international markets, was controlled. 
ANALYSIS

\section{Descriptive statistics}

Table 2 shows descriptive statistics and intercorrelations for all variables, including both main variables and control variables.

Table 2. Descriptive statistics and correlation matrix

\begin{tabular}{|c|c|c|c|c|c|c|c|}
\hline \multicolumn{8}{|l|}{ I. Main Variables } \\
\hline & Mean & S.D. & 1 & 2 & 3 & 4 & 5 \\
\hline 1. Short/Medium-term Alliances & 3.18 & 0.96 & 1 & & & & \\
\hline 2. Long-term Alliances & 4.08 & 1.11 & $0.53^{* *}$ & 1 & & & \\
\hline 3. Market Capability & 1.86 & 1.33 & $0.29^{* *}$ & $0.32^{* *}$ & 1 & & \\
\hline 4. Managerial Capability & 4.44 & 0.95 & $0.31^{* *}$ & $0.38^{* *}$ & 0.08 & 1 & \\
\hline 5. Technological Capability & 2.54 & 1.22 & $0.24^{* *}$ & $0.23^{* *}$ & $-0.19^{*}$ & -0.06 & 1 \\
\hline \multicolumn{8}{|l|}{$\mathrm{N}=736 ;^{* *} \mathrm{p}<0.01$ level; ${ }^{*} \mathrm{p}<0.05$ level } \\
\hline \multicolumn{8}{|l|}{ II. Control Variables } \\
\hline & Mean & S.D. & 1 & 2 & 3 & 4 & 5 \\
\hline 1. Natural Resources & 0.98 & 0.24 & 1 & & & & \\
\hline 2. Manufacturing & 0.21 & 0.13 & -0.13 & 1 & & & \\
\hline 3. Firm Age ${ }^{a}$ & 4.14 & 3.21 & $0.20^{* *}$ & $0.19^{*}$ & 1 & & \\
\hline 4. Firm Size $^{\mathrm{a}}$ & 3.99 & 3.03 & $0.36^{* *}$ & $0.21^{* *}$ & $0.21^{*}$ & 1 & \\
\hline 5. International Experiences & 5.12 & 9.11 & $0.19^{*}$ & 0.10 & $0.16^{*}$ & -0.03 & 1 \\
\hline \multicolumn{8}{|l|}{${ }^{* *} \mathrm{p}<0.01$ level; " $\mathrm{p}<0.05$ level; a Logarithmic } \\
\hline
\end{tabular}

Based upon Table 2, the averages and the standard deviations moderately indicate that there is not substantial variation across different capabilities. In addition, the average links with managerial capability measure is 4.44 , and the standard deviation of 0.95 shows that managerial capability is the least varied variable as one of the core capability of partners in strategic alliances. Table 2; also provide some valuable insights about the sample, as it shows that the size of partner plays a more significant role than firm age in the formation of strategic alliances in natural resources and manufacturing.

\section{Which capability for which strategic alliances?}

To answer the question about the most effective capability in each alliance due to its time frame, the results are presented in models $A$ to $D$ of Table 3. Each of the reported estimates is from panel-level regressions allowing for random effects, heteroskedasticity and clustering of the standard errors. Model A and B are related to short/medium-term alliances, while the results of analyses for long-term alliances are presented in model C and D. Also, 
models $A$ and $C$ include only fixed effects (control variables), while model $B$ and $D$ include both fixed effects and random effects.

Table 3. Effective partner capabilities due to time frame of the strategic alliances

\begin{tabular}{|c|c|c|c|c|c|c|c|c|}
\hline & \multicolumn{4}{|c|}{ Short/Medium-term Alliances } & \multicolumn{4}{|c|}{ Long-term Alliances } \\
\hline & \multicolumn{2}{|c|}{ Model A } & \multicolumn{2}{|c|}{ Model B } & \multicolumn{2}{|c|}{ Model C } & \multicolumn{2}{|c|}{ Model D } \\
\hline & $\beta$ & z-stat & $\beta$ & z-stat & $\beta$ & z-stat & $\beta$ & z-stat \\
\hline \multicolumn{9}{|l|}{ Fixed Effects (controls) } \\
\hline Intercept & 0.662 & 0.347 & $3.021^{*}$ & 2.227 & 1.426 & 0.965 & $4.209^{* *}$ & 2.818 \\
\hline $\begin{array}{l}\text { Industry } 1 \text { (Natural } \\
\text { Resources) }\end{array}$ & $0.186^{*}$ & 1.523 & $0.143^{+}$ & 1.611 & $0.166^{*}$ & 1.403 & $0.184^{*}$ & 1.772 \\
\hline Industry 2 (Manufacturing) & $0.141^{+}$ & 1.208 & 0.106 & 1.019 & $0.150^{*}$ & 1.189 & $1.149^{+}$ & 1.276 \\
\hline Firm Age & $1.149^{+}$ & 1.040 & 1.116 & 0.801 & $0.166^{*}$ & 1.210 & $1.152^{*}$ & 1.602 \\
\hline Firm Size & $0.171^{*}$ & 1.224 & $1.130^{+}$ & 1.082 & $0.189^{* *}$ & 1.544 & $1.157^{*}$ & 1.214 \\
\hline International Experiences & $-0.133^{+}$ & 0.992 & -0.079 & 0.560 & $0.129^{+}$ & 1.077 & -0.109 & 0.558 \\
\hline \multicolumn{9}{|l|}{ Random Effects } \\
\hline Market Capability & & & $0.373^{* *}$ & 2.990 & & & $0.229^{*}$ & 1.372 \\
\hline Managerial Capability & & & $0.361^{* *}$ & 2.628 & & & $0.422^{* *}$ & 3.612 \\
\hline Technological Capability & & & $0.221^{+}$ & 1.139 & & & $0.390^{* *}$ & 2.840 \\
\hline Chi-squared Statistic & $320.5^{*}$ & & $466.4^{*}$ & & $348.2^{*}$ & & $600.2^{*}$ & \\
\hline R-squared & 0.214 & & 0.239 & & 0.219 & & 0.291 & \\
\hline Adjusted R-squared & 0.199 & & 0.220 & & 0.203 & & 0.268 & \\
\hline
\end{tabular}

Notes: $\mathrm{N}=736$; Results are based on random-effects regressions with controls for heteroskedasticity, autocorrelation, and industry-level clustering. ${ }^{* *} p<0.01$ level; ${ }^{p} p<0.05$ level; ${ }^{+} p<0.1$ level. All significance tests are two-tailed.

The results presented in Table 3 show that the coefficients for managerial capability are positive and statistically significant in both the short/mediumterm alliances $(B=0.361 ; z=2.628 ; p<0.01)$ and long-term alliances $(B=0.422$; $z=3.612 ; p<0.01)$, suggesting that both forms of short/medium-term and long-term alliances place emphasis on this criterion as a determinant partner capability. Furthermore, the comparison between $B$ coefficients and $z$ statistics shown in Table 3 is indicating that long-term alliances emphasize more heavily this criterion than do short/medium-term ones.

The coefficients presented in Table 3 for market capability is also positive and significant with different levels for both short/medium-term alliances and long-term alliances. However, the difference between significant level suggests that short/medium-term alliances are more determined by market 
capability $(B=0.373 ; z=2.990 ; p<0.01)$ and increases in the time frame of strategic alliances resulted in lower level of influence $(b=0.229 ; z=1.372 ; p<$ 0.05) for market capability.

Along with these capabilities, analysis showed that technological capability is also a determinant capability in strategic alliances. Table 3 shows that the coefficient and $z$ statistic for technological capability is positive and weakly significant in the short/medium-term alliances $(B=0.221 ; z=1.139 ; p$ $<0.1)$, but the coefficient for this capability is strongly significant $(B=0.390$; $z=2.840 ; p<0.01$ ) in the long-term alliances. Hence, the results show that technological capability has a contradictory behavior to market capability. It is also notable that a previous alliance experience is not statistically significant in both forms of alliances.

Due to the findings, the following chart could be presented to provide an image of effectiveness of the various partner capabilities in strategic alliances due to their time frame. As depicted in Figure 1, whenever the time frame of strategic alliances is higher, the impact of managerial capability and technological capability is stronger. Capabilities are depicted by the $\beta$ coefficient.

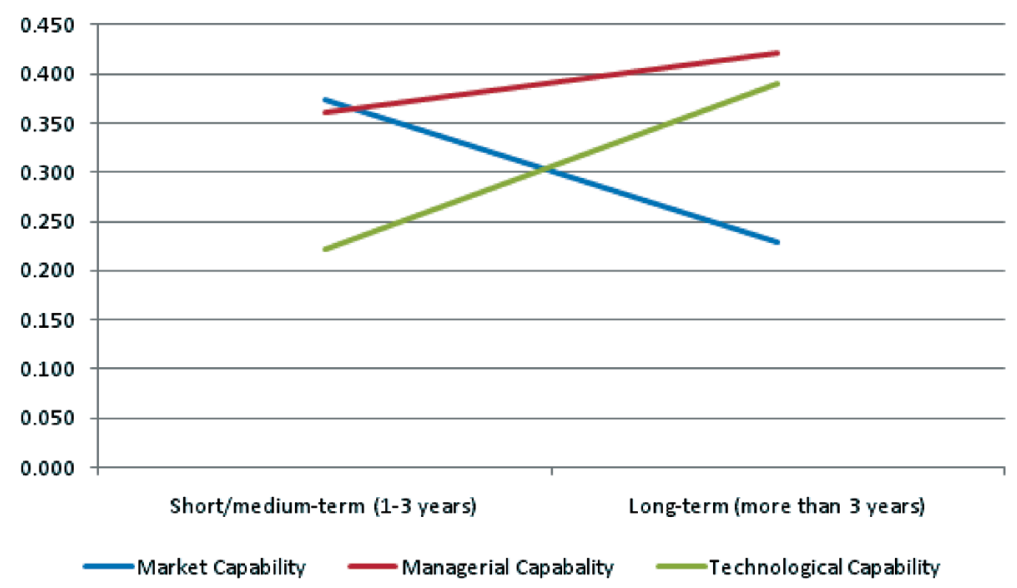

Figure 1. Relationship between effectiveness of partner capabilities and time frame of alliances

\section{Sensitivity analysis}

In order to reach reliable results, a sensitivity test was carried out to ascertain whether findings are robust to a closer matching of the time periods for 
defining alliances (i.e. short/medium-term in less than three years and longterm for more than three years). The alliance time frame measured using data from shorter time spans (i.e. in one year, and for the second time, in two years), which are a closer match to the alliances outcome. This sensitivity analysis found support for findings at the 1 percent significance level and showed that findings are strongly robust to this alternative estimation methodology.

\section{DISCUSSION AND CONCLUSION}

Drawing on the resource-based view, this research contributes to a greater understanding of the different partner capabilities. Previous studies stated that partner selection is a critical consideration in the pre-agreement phase (Mindruta, Moeen \& Agarwal, 2016), and is vital to alliances' success (Hitt et al., 2000). Researchers generally refer to a broad concept of partner characteristics including assets, skills and capabilities. Also, it is important to consider the differences between short/medium-term and long-term alliances, since the short/medium-term cooperative agreements prevent partners from establishing trust or reputation capital needed in the long-term ones (Bignoux, 2006). Thus, it is necessary to distinguish between partner assets, skills and capabilities due to the time frame of alliances. With the focus on partner capabilities, the current research findings provide insight about which partner capability has a greater effect on strategic alliances due to the intended time frame of alliances, and then, which partner capability should have priority as a criterion for alliance formation.

The current study provides several empirical, theoretical, and practical contributions. The most important, is the contingency between partner capabilities and the time frame of alliances. Previous studies didn't provide evidence about the relationship between specific partner capabilities and the time frame of alliances. In doing so, this research extends the literature by suggesting that alliance time frame has an important role in determining the relative importance of partner capabilities. Findings show managerial capability plays a vital role as a partner capability in both of short/mediumterm alliances and long-term ones. It is also inferred that different strategic alliances due to their time frame, put a different emphasis on partner capability in attaining the desired level of performance. Based upon evidence, technological capability gains a more determining role in long-term alliances, while market capability is more important in short/medium-term alliances. This difference may be influenced by the nature of alliances. On-time market entry is a critical criterion in short/medium-term alliances, while firms seek 
reliable advantage in more durable alliances which are rooted in technological innovation.

In terms of empirical contributions, this is one of the few empirical studies focusing on international strategic alliances from a developing economy context. The results provide empirical evidence about the most important partner capabilities that are key determinants of performance for developing economies-based alliances in both short/medium-term alliances and long-term alliances. In addition, most of the previous research focused on the broad concept of partner characteristics and presented general models that assume the factors that drive partner attractiveness in every alliance types. However, this research focused only on a narrower domain of partner capabilities and the findings show the importance of studying the alliance time frame, and strongly support the idea that alliance partner capabilities are contingent on the differential inherent in short/medium-term strategic alliances and long-term strategic alliances. The research also contributes to practice by providing an insight into strategic alliances' partner selection; and particularly the distinctive type of capabilities of partners. Partner selection is a critical decision in the pre-agreement phase (Mindruta, Moeen \& Agarwal, 2016), and plays a vital role in alliances' success (Hitt et al., 2000). The current research findings help executives understand the basis on which partner capabilities should have priority on their decisions about alliances' partners. Executives, who understand the differences and similarities of alliances partner capabilities, can form more successful alliances regarding their purposes.

Building on the findings of the current research and its implications, future research could examine partner capabilities under different alliance attributes. Identifying the way partner capabilities affect alliances can help researchers and practitioners to develop more efficient alliances, especially in international markets. Also, the relationships examined in this study should be investigated in other geographical regions to determine whether the highly significant results of this study are stable.

\section{References}

Ahlstrom, D., Levitas, E., Hitt, M. A., Dacin, M. T., \& Zhu, H. (2014). The three faces of China: Strategic alliance partner selection in three ethnic Chinese economies. Journal of World Business, 49(4), 572-585.

Ahuja, G. (2000). The duality of collaboration: Inducements and opportunities in the formation of interfirm linkages. Strategic Management Journal, 21(3), 317-343. 
Ahuja, G., Polidoro, F., \& Mitchell, W. (2009). Structural homophily or social asymmetry? The formation of alliances by poorly embedded firms. Strategic Management Journal, 30(9), 941-958.

Al-Laham, A., Amburgey, T. L., \& Baden-Fuller, C. (2010). Who is my partner and how do we dance? Technological collaboration and patenting speed in US biotechnology. British Journal of Management, 21(3), 789-807.

Arranz, N., Arroyabe, M. F., \& Fdez. de Arroyabe, J. C. (2016). Alliance building process as inhibiting factor for SME international alliances. British Journal of Management, 27(3), 497-515.

Badir, Y. F., \& O'Connor, G. C. (2015). The formation of tie strength in a strategic alliance's first new product development project: The influence of project and partners' characteristics. Journal of Product Innovation Management, 32(1), 154-169.

Bae, J., \& Insead, M. G. (2004). Partner substitutability, alliance network structure, and firm profitability in the telecommunications industry. Academy of Management Journal, 47(6), 843-859.

Bakker, R. M. (2016). Stepping in and stepping out: Strategic alliance partner reconfiguration and the unplanned termination of complex projects. Strategic Management Journal, 37(9), 1919-1941.

Bierly, P. E., \& Gallagher, S. (2007). Explaining alliance partner selection: Fit, trust and strategic expediency. Long Range Planning, 40(2), 134-153.

Bignoux, S. (2006). Short-term strategic alliances: A social exchange perspective. Management Decision, 44(5), 615-627.

Chand, M., \& Katou, A. A. (2012). Strategic determinants for the selection of partner alliances in the Indian tour operator industry: A cross-national study. Journal of World Business, 47(2), 167-177.

Chen, H. M., \& Tseng, C. H. (2005). The performance of marketing alliances between the tourism industry and credit card issuing banks in Taiwan. Tourism Management, 26(1), 15-24.

Chen, S. H., Lee, H. T., \& Wu, Y. F. (2008). Applying ANP approach to partner selection for strategic alliance. Management Decision, 46(3), 449-465.

Cummings, J. L., \& Holmberg, S. R. (2012). Best-fit alliance partners: The use of critical success factors in a comprehensive partner selection process. Long Range Planning, 45(2), 136-159.

Das, T. K., \& Teng, B. S. (2002). The dynamics of alliance conditions in the alliance development process. Journal of Management Studies, 39(5), 725-746.

Doherty, A.M. (2009). Market and partner selection processes in international retail franchising. Journal of Business Research, 62(5), 528-534.

Dong, L., \& Glaister, K. W. (2006). Motives and partner selection criteria in international strategic alliances: Perspectives of Chinese firms. International Business Review, 15(6), 577-600.

Dussauge, P., Garrette, B., \& Mitchell, W. (2000). Learning from competing partners: Outcomes and durations of scale and link alliances in Europe, North America and Asia. Strategic Management Journal, 21(2), 99-126. 
Gomes, E., Barnes, B. R., \& Mahmood, T. (2016). A 22 year review of strategic alliance research in the leading management journals. International Business Review, 25(1), 15-27.

Gulati, R., Lavie, D., \& Singh, H. (2009). The nature of partnering experience and the gains from alliances. Strategic Management Journal, 30(11), 1213-1233.

Hess, A. M., \& Rothaermel, F. T. (2011). When are assets complementary? Star scientists, strategic alliances, and innovation in the pharmaceutical industry. Strategic Management Journal, 32(8), 895-909.

Hitt, M. A., Ahlstrom, D., Dacin, M. T., Levitas, E., \& Svobodina, L. (2004). The institutional effects on strategic alliance partner selection in transition economies: China vs. Russia. Organization Science, 15(2), 173-185.

Hitt, M. A., Dacin, M. T., Levitas, E., Arregle, J. L., \& Borza, A. (2000). Partner selection in emerging and developed market contexts: Resource-based and organizational learning perspectives. Academy of Management Journal, 43(3), 449-467.

Jalali, S.H. (2012). The effect of export promotion programmes on export performance: evidence from Iranian food manufacturers. International Journal of Business and Globalisation, 9(2), 122-133.

Krishnan, R., Martin, X., \& Noorderhaven, N. G. (2006). When does trust matter to alliance performance? Academy of Management Journal, 49(5), 894917.

Lee, H. U., \& Park, J. H. (2006). Top team diversity, internationalization and the mediating effect of international alliances. British Journal of Management, 17(3), 195-213.

Li, D., \& Ferreira, M. P. (2008). Partner selection for international strategic alliances in emerging economies. Scandinavian Journal of Management, 24(4), 308-319.

Li, D., Eden, L., Hitt, M. A., \& Ireland, R. D. (2008). Friends, acquaintances, or strangers? Partner selection in R\&D alliances. Academy of Management Journal, 51(2), 315-334.

Lu, J. W., \& Beamish, P. W. (2006). Partnering strategies and performance of SMEs' international joint ventures. Journal of Business Venturing, 21(4), 461-486.

Luo, Y. (2002). Partnering with foreign businesses: perspectives from Chinese firms. Journal of Business Research, 55(6), 481-493.

Meuleman, M., Lockett, A., Manigart, S., \& Wright, M. (2010). Partner selection decisions in interfirm collaborations: The paradox of relational embeddedness. Journal of Management Studies, 47(6), 995-1019.

Mindruta, D., Moeen, M., \& Agarwal, R. (2016). A two-sided matching approach for partner selection and assessing complementarities in partners' attributes in inter-firm alliances. Strategic Management Journal, 37(1), 206-231.

Mitsuhashi, H. (2002). Uncertainty in selecting alliance partners: The three reduction mechanisms and alliance formation process. The International Journal of Organizational Analysis, 10(2), 109-133. 
Mitsuhashi, H., \& Greve, H. R. (2009). A matching theory of alliance formation and organizational success: Complementarity and compatibility. Academy of Management Journal, 52(5), 975-995.

Nakos, G., Brouthers, K. D., \& Dimitratos, P. (2014). International alliances with competitors and non-competitors: The disparate impact on SME international performance. Strategic Entrepreneurship Journal, 8(2), 167-182.

Nielsen, B. B. (2003). An empirical investigation of the drivers of international strategic alliance formation. European Management Journal, 21(3), 301-322.

Phene, A., \& Tallman, S. (2014). Knowledge spillovers and alliance formation. Journal of Management Studies, 51(7), 1058-1090.

Roy, J.P. (2012). IJV partner trustworthy behavior: The role of host country governance and partner selection criteria. Journal of Management Studies, 49(2), 332-355.

Shah, R. H., \& Swaminathan, V. (2008). Factors influencing partner selection in strategic alliances: The moderating role of alliance context. Strategic Management Journal, 29(5), 471-494.

Solesvik, M. Z., \& Westhead, P. (2010). Partner selection for strategic alliances: Case study insights from the maritime industry. Industrial Management and Data Systems, 110(6), 841-860.

Vasudeva, G., Spencer, J. W., \& Teegen, H. J. (2013). Bringing the institutional context back in: A cross-national comparison of alliance partner selection and knowledge acquisition. Organization Science, 24(2), 319-338.

Wu, W. Y., Shih, H. A., \& Chan, H. C. (2009). The analytic network process for partner selection criteria in strategic alliances. Expert Systems with Applications, 36(3), 4646-4653.

Wyatt, M. R., Pathak, S. B., \& Zibarras, L. D. (2010). Advancing selection in an SME: Is best practice methodology applicable?. International Small Business Journal, 28(3), 258-273.

Xia, J. (2011). Mutual dependence, partner substitutability, and repeated partnership: the survival of cross-border alliances. Strategic Management Journal, 32(3), 229-253.

Yu, J., Gilbert, B.A., \& Oviatt, B.M. (2011). Effects of alliances, time, and network cohesion on the initiation of foreign sales by new ventures. Strategic Management Journal, 32(4), 424-446.

Zhang, Y., Duysters, G., \& Filippov, S. (2012). Chinese firms entering Europe: Internationalization through acquisitions and strategic alliances. Journal of Science and Technology Policy in China, 3(2), 102-123.

\footnotetext{
Abstract (in Polish)

Wybór partnera jest jednym z najczęściej poruszanych kwestii w literaturze dotyczq̨cej sojuszy strategicznych. Większość badań koncentruje się głównie na ogólnych cechach partnera i prezentuje modele koncepcyjne jego wyboru, odnoszqce się do obrazu klanu i ograniczonych fragmentów puzzli w wyborze partnera. Bazujqqc na podejściu zasobowym, artykut sugeruje, że wybór partnera zależy od
} 
przewidywanych ramami czasowymi strategicznych sojuszy $i$ przedstawia nowe ramy pojęciowe, które sprawdzajq odpowiedniq zdolność partnera do strategicznych sojuszy w przypadku zarówno krótko- lub średnioterminowych sojuszy, jak również długoterminowych. Na podstawie empirycznych dowodów z 736 sojuszy w regionie CEE, ustalenia wskazujq na różnice między różnymi kompetencjami partnera w krótko-, średnio- $i$ długoterminowych sojuszach. W zwiq̨zku z tym znaczenie kompetencji technologicznych wzrasta wraz z liczbq sojuszy w danym roku. Co więcej, znaczenie kompetencji rynkowych znacznie spada, gdy alianse trwaja dłużej. Słowa kluczowe: strategiczny sojusz; ramy czasowe sojuszu, kompetencje partnera, wybór partnera.

\section{Biographical note}

S. Hossein Jalali is a Ph.D. scholar in Business Strategy at the University of Tehran. His research interests include strategic alliances, corporate strategy and strategy implementation. His works have been published in several journals including International Journal of Strategic Business Alliances, International Journal of Business and Globalisation, Serbian Journal of Management, and South-Eastern Europe Journal of Economics, among others. 
